\title{
Genetic parameters of colostrum traits in Holstein dairy cows
}

\author{
A. Soufleri, ${ }^{1}$ G. Banos,,${ }^{1,2}$ N. Panousis, ${ }^{3}$ D. Fletouris, ${ }^{4}$ G. Arsenos, ${ }^{1}$ and G. E. Valergakis ${ }^{1 *}$ \\ ${ }^{1}$ Laboratory of Animal Husbandry, Faculty of Veterinary Medicine, School of Health Sciences, Aristotle University of Thessaloniki, Box 393, \\ GR-54124 Thessaloniki, Greece \\ ${ }^{2}$ Scotland's Rural College and Roslin Institute, Edinburgh, EH25 9RG United Kingdom \\ ${ }^{3}$ Clinic of Farm Animals, Faculty of Veterinary Medicine, School of Health Sciences, Aristotle University of Thessaloniki, GR-54124 Thessaloniki, \\ Greece \\ ${ }^{4}$ Laboratory of Milk Hygiene and Technology, Faculty of Veterinary Medicine, School of Health Sciences, Aristotle University of Thessaloniki, \\ GR-54124 Thessaloniki, Greece
}

\section{ABSTRACT}

The main objective of this study was to assess the genetic background of colostrum yield and quality traits after calving in Holstein dairy cows. The secondary objective was to investigate genetic and phenotypic correlations among laboratory-based and on-farm-measured colostrum traits. The study was conducted in 10 commercial dairy herds located in northern Greece. A total of 1,074 healthy Holstein cows with detailed pedigree information were examined from February 2015 to September 2016. All cows were clinically examined on the day of calving and scored for body condition. All 4 quarters were machine-milked, and a representative and composite colostrum sample was collected and examined. Colostrum total solids (TS) content was determined on-farm using a digital Brix refractometer. Colostrum fat, protein, and lactose contents were determined using an infrared milk analyzer, and energy content was calculated using National Research Council (2001) equations. Dry period length (for cows of parity $\geq 2$ ), milk yield of previous 305-d lactation (for cows of parity $\geq 2$ ), age at calving, parity number, season of calving, time interval between calving and first colostrum milking, and milk yield were recorded. Each trait (colostrum yield and quality traits) was analyzed with a univariate mixed model, including fixed effects of previously mentioned factors and the random animal additive genetic effect. All available pedigrees were included in the analysis, bringing the total animal number to 5,662. Estimates of (co)variance components were used to calculate heritability for each trait. Correlations among colostrum traits were estimated with bivariate analysis using the same model. Mean per-

Received June 3, 2019.

Accepted July 31, 2019.

*Corresponding author: geval@vet.auth.gr centage $( \pm \mathrm{SD})$ colostrum TS, fat, protein, and lactose contents were $25.8 \pm 4.7,6.4 \pm 3.3,17.8 \pm 4.0$, and 2.2 $\pm 0.7 \%$, respectively; mean energy content was 1.35 $\pm 0.3 \mathrm{Mcal} / \mathrm{kg}$ and mean colostrum yield was $6.18 \pm$ $3.77 \mathrm{~kg}$. Heritability estimates for the above colostrum traits were $0.27,0.21,0.19,0.15,0.22$, and 0.04 , respectively. Several significant genetic and phenotypic correlations were derived. The genetic correlation of TS content measured on-farm with colostrum protein was practically unity, whereas the correlation with energy content was moderate (0.61). Fat content had no genetic correlation with TS content; their phenotypic correlation was positive and low. Colostrum yield was not correlated genetically with any of the other traits. In conclusion, colostrum quality traits are heritable and can be amended with genetic selection.

Key words: dairy cow, colostrum quality, genetic parameters

\section{INTRODUCTION}

Timely administration of high-quality colostrum in adequate quantity is of great importance for calf health and survival. The key roles of colostrum are to ensure the passive transfer of immunity and provide nutritional support to newborn calves, especially energy, during the critical first hours of life (Blum and Hammon, 2000; Weaver et al., 2000; McGuirk and Collins, 2004).

Bovine colostrum consists of a blend of blood serum components and mammary secretions; the main constituents, however, are protein and fat, which comprise about $90 \%$ of total colostrum solids (Foley and Otterby, 1978; Kehoe et al., 2007). The first secretion collected after calving (first milking or "true" colostrum) has the highest concentration of these 2 components, which largely define colostrum quality. Their concentrations are reduced at the subsequent milkings ("transition" milk) and reach the lowest levels in whole milk (Foley and Otterby, 1978; Tsioulpas et al., 2007). Deviations from high quality could lead to an increased rate of 
preweaning morbidity and mortality (Weaver et al., 2000; Jaster, 2005).

Protein is the component with the highest concentration in colostrum and is of serum (mostly immunoglobulins, 70-80\%; Larson, 1992) and mammary (caseins, 20-30\%) origin. Colostrum immunoglobulins are essential for bovine neonates. The placental structure of the dam does not allow their transmission to the fetus (Arthur et al., 1996). Consequently, calves are born agammaglobulinemic and rely on intake and absorption of colostrum for passive transfer of immunity (Godden, 2008).

The immunological significance of colostrum is well explored in the relevant literature; in contrast, its nutritional importance - especially that of fat content - is not equally well addressed. Colostrum fat content is 50 to $60 \%$ higher than that of whole milk (Foley and Otterby, 1978) and constitutes the main energy source for body temperature maintenance and thermogenesis (Morrill et al., 2012). This is a critical aspect of colostrum feeding to newborn calves, especially for those subjected to cold stress conditions.

Colostrum yield and composition vary substantially among cows and herds and may be affected by a multitude of environmental and management factors. Several dry-cow management practices have been proposed and implemented to ensure an ample supply of highquality colostrum to calves (Kehoe et al., 2007; Morrill et al., 2012; Dunn et al., 2017). However, the genetic component of Holstein colostrum traits has not been researched to date, nor has the feasibility of improving their colostrum quality and yield with genetic selection.

Colostrum composition can be accurately assessed in the laboratory but a standardized phenotypic colostrum yield and component data set is difficult to build, because it is based on one sampling per lactation collected within a specific timeframe after calving. Moreover, direct measurement of immunoglobulin content, which is the most significant quality trait, using radial immunodiffusion (Fleenor and Stott, 1981) or ELISA (Gelsinger et al., 2015) techniques is expensive and time consuming and, therefore, not suitable for the creation of large phenotypic data sets. This constraint may be overcome by measuring colostrum total solids (TS) content with a Brix refractometer, a quick, inexpensive, on-farm method that provides an indirect but reliable assessment of immunoglobulin concentration (Bielmann et al., 2010; Bartier et al., 2015). However, estimates of the genetic and phenotypic correlation between on-farm Brix measurements and laboratorybased colostrum fat, lactose, and energy contents are missing from the literature. Such estimates would offer valuable information on the utility of TS measured with Brix as a proxy of overall colostrum quality in genetic selection programs.

The objectives of the present study were to (1) assess the genetic background of colostrum yield and quality traits, and (2) investigate genetic and phenotypic correlations among laboratory-based and on-farm measured colostrum traits.

\section{MATERIALS AND METHODS}

This research was conducted in compliance with institutional guidelines and approved by the Research Committee of the Aristotle University of Thessaloniki, Greece. All farmers gave informed consent for their cows to be included in the study.

\section{Animals and Management}

A total of 1,074 healthy Holstein dairy cows from 10 commercial dairy herds in northern Greece were included in the study. Herd size ranged from 90 to 300 cows. The distribution across parities was $387,311,181$, and 195 cows for parities $1,2,3$, and $\geq 4$, respectively. Farms were visited between February 2015 and September 2016 for sample collection and data recording. Dry cows were housed in straw yards and were fed TMR formulated to meet or exceed $\mathrm{NE}_{\mathrm{L}}$ and $\mathrm{MP}$ requirements, according to NRC (2001) recommendations.

\section{Clinical Examination and Colostrum Collection and Sampling}

All cows were clinically examined by the first author (a qualified veterinarian) on the day of calving; cows exhibiting any sign of disease or altered colostrum appearance (e.g., watery, clots, blood) were excluded from the study. At the same time, cows were body condition scored using the 1-5 scale of Ferguson et al. (1994) in increments of 0.25 , where 1 corresponds to emaciated and 5 to obese animals. All 4 udder quarters, which had not been milked or suckled by the calf, were completely milked using a portable milking machine into a clean and sanitized steel churn. Time interval between calving and first colostrum milking was recorded; depending on calving time and farm milking schedule, colostrum was collected from 10 to 960 min after calving. Colostrum was transferred into plastic graded milk buckets and weighed; volume and weight were recorded (hereafter referred to as colostrum yield). Colostrum from each cow was agitated for at least 2 min to ensure an even distribution of constituents; a 100-mL sample was collected and divided into 2 plastic vials $(50 \mathrm{~mL}$ each). One was used for on-farm analysis and the second, 
destined for chemical analysis, was properly labeled, placed in a cooler, transported to the laboratory, and frozen immediately upon arrival at $-20^{\circ} \mathrm{C}$.

\section{On-Farm Determination of Colostrum Quality}

Colostrum TS, an indirect assessment of colostrum immunoglobulin concentration, was measured immediately after sampling by using a digital Brix refractometer (PAL-1, Atago, Tokyo, Japan). The instrument measures the refractometric index of liquids on the Brix scale. It has a measurement range from 0 to $53 \%$, is independent of ambient temperature $\left(0-99^{\circ} \mathrm{C}\right)$, and has a high accuracy $( \pm 0.1 \%)$. Calibration was carried out before each measurement using distilled water. The colostrum-containing vial was agitated at least 10 times to ensure an even distribution of components, and a quantity of $0.3 \mathrm{~mL}$ was subsequently placed on the prism surface. All measurements were performed in duplicate, recorded, and then averaged. A measurement of $\geq 22 \%$ (Brix value) was considered indicative of high-quality colostrum (Bielmann et al., 2010).

\section{Laboratory Determination of Colostrum Composition}

Frozen colostrum samples were thawed in a water bath at $40 \pm 2^{\circ} \mathrm{C}$; vials were inverted 10 times to thoroughly mix the colostrum and ensure an even distribution of constituents. Colostrum fat, protein, and lactose contents were determined using an infrared milk analyzer (MilkoScan Minor, Foss, Hillerød, Denmark) after a 1:4 dilution with distilled water. All analyses were performed at the Laboratory of Milk Hygiene and Technology of the Faculty of Veterinary Medicine, Aristotle University of Thessaloniki (Thessaloniki, Greece).

\section{Calculation of Colostrum Net Energy Content}

Net energy content of colostrum was calculated according to the NRC (2001) equation:

$$
\begin{gathered}
{[0.057 \times \mathrm{CP}(\%)+0.092 \times \text { fat }(\%)+0.0395} \\
\times \text { lactose }(\%)] \times 0.97 \times 0.96 \times 0.86 .
\end{gathered}
$$

\section{Final Data Set}

Colostrum yield, fat, protein, lactose and energy contents and TS content (\% Brix value) were matched with data extracted from farm records, including dry period length (for cows with parity $\geq 2$ ), milk yield of previous 305 -d lactation (for cows with parity $\geq 2$ ), age at calving (in months), and parity number, and with data recorded during farm visits such as season of calving (spring, autumn, winter, summer), BCS at calving, and time interval between calving and first colostrum milking.

Pedigree information spanning 6 ancestral generations was available for all 1,074 cows, bringing the total number of animals in the analysis to 5,662 .

\section{Statistical Analysis}

In the first instance, each trait (TS, fat, protein, lactose, and energy contents, and colostrum yield) was analyzed separately using the following mixed model:

$$
\begin{aligned}
Y_{i j k m q}=H Y S_{i} & +L_{j}+M_{k}+\beta_{1} \times d u r+\beta_{2} \times \text { time } \\
+Q_{m}+ & \beta_{3} \times B C S+\beta_{4} \times \text { milk }+\beta_{5} \\
& \times a g e+A_{q}+e_{i j k m q},
\end{aligned}
$$

where $Y_{i j k m q}$ is the dependent variable (colostrum trait record); $H Y S_{i}$ is the fixed effect of herd-year-season of calving $i$ (80 levels); $L_{j}$ is the fixed effect of number of lactation $j$ (4 levels); $M_{k}$ is the fixed effect of calendar month when the record was taken $k$ (12 levels); $\beta_{1}$ is the linear regression on duration of previous dry period (dur); $\beta_{2}$ is the linear regression on time of colostrum collection (time); $Q_{m}$ is the fixed effect of colostrum quantity class $m$ ( 3 levels; content traits only); $\beta_{3}$ is the linear regression on BCS; $\beta_{4}$ is the linear regression on milk yield of previous $305-d$ lactation (milk); $\beta_{5}$ is the linear regression on cow age at calving (age); $A_{q}$ is the random genetic effect of individual animal $q$ including all pedigree data (5,662 animals); and $e_{i j k m q}$ is the random residual term.

Dry period length, milk yield of previous 305-d lactation, time interval between calving and colostrum collection, BCS, and age at calving were included in the model as covariates. Parity number was grouped as $1,2,3$, or $\geq 4$. Season of calving was categorized as winter (December, January, February), spring (March, April, May), summer (June, July, August), and autumn (September, October, November). Colostrum yield was classified as $\leq 4,4.1-8.4$, and $\geq 8.5 \mathrm{~kg}$. The fixed effects in the model were fitted after preliminary analyses had confirmed their statistically significant effect $(P<$ $0.05)$ on the traits.

Estimates of variance components were used to calculate heritabilities for each trait, using the following equation:

$$
h^{2}=\frac{\sigma_{\alpha}^{2}}{\sigma_{p}^{2}},
$$


Table 1. Descriptive statistics of colostrum traits from 1,074 Holstein dairy cows

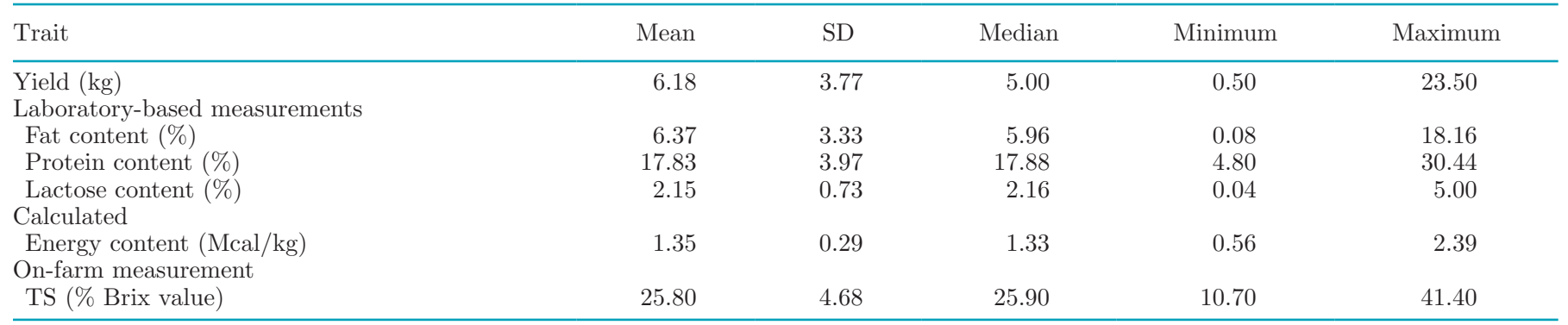

where $h^{2}$ is the heritability estimate, $\sigma_{\alpha}^{2}$ is the additive genetic variance estimate, and $\sigma_{p}^{2}$ is the phenotypic variance estimate.

Subsequently, in a series of bivariate statistical analyses based on the same model, genetic and phenotypic correlations among all traits were derived from co-variance component estimates using the following equation:

$$
r_{(\alpha, p)}=\frac{\operatorname{Cov}_{(\alpha, p)}(\mathrm{X}, \mathrm{Y})}{\sqrt{\sigma_{(\alpha, p) \mathrm{X}}^{2} \times \sigma_{(\alpha, p) Y}^{2}}},
$$

where $\operatorname{Cov}_{(\alpha, p)}(\mathrm{X}, \mathrm{Y})$ is the additive genetic $\left(\operatorname{Cov}_{\alpha}\right)$ or phenotypic $\left(\operatorname{Cov}_{p}\right)$ covariance of traits $\mathrm{X}$ and $\mathrm{Y}$, and $\sigma_{(\alpha, p) \mathrm{X}}^{2}$ and $\sigma_{(\alpha, p) Y}^{2}$ are the respective genetic $\left(\sigma_{\alpha}^{2}\right)$ and phenotypic $\left(\sigma_{p}^{2}\right)$ variances.

All analyses were conducted with the statistical software package ASREML (Gilmour et al., 2009). Standard errors were derived from the same software package. In all cases, statistical significance was set at $P<0.05$.

\section{RESULTS}

Descriptive statistics for all studied traits are presented in Table 1. Estimates of variance components and heritability for the studied traits are presented in Table 2.
Significant $(P<0.05)$ additive genetic variance was found for all colostrum traits except yield. Heritability estimates of colostrum fat, energy, and TS contents were moderate $(0.21,0.22$, and 0.27 , respectively), whereas those of protein and lactose contents were moderately low ( 0.15 and 0.19 , respectively). All heritability estimates were significantly greater than zero $(P<0.05)$ except that for colostrum yield.

Statistically significant $(P<0.05)$ phenotypic and genetic correlations between traits are presented in Table 3. The genetic correlation of TS content measured on-farm with colostrum protein was practically unity (0.97), suggesting that the former can be viewed as an excellent proxy for the latter. Total solids content was moderately correlated genetically with energy content (0.61). Fat content had no genetic correlation with TS content; their phenotypic correlation was positively low (0.15). Colostrum yield was not correlated genetically with any of the other traits, as expected given the absence of significant genetic variance in the former.

\section{DISCUSSION}

The key objective of the present study was to estimate genetic parameters of colostrum yield and fat, protein, lactose, energy, and TS content (a proxy for protein content). To the best of our knowledge, this is the first genetic study of Holstein colostrum traits. Obviously, a large data set was required and therefore, the study was designed to include more than 1,000 Hol-

Table 2. Variance component and heritability estimates of colostrum traits ${ }^{1}$

\begin{tabular}{|c|c|c|c|c|}
\hline Trait & $\sigma_{p}^{2}$ & $\sigma_{\alpha}^{2}$ & $\sigma_{r}^{2}$ & $h^{2}$ \\
\hline Fat content $(\%)$ & $9.417(0.43)^{*}$ & $1.986(0.78)^{*}$ & $7.431(0.74)^{*}$ & $0.21(0.08)^{*}$ \\
\hline Protein content (\%) & $14.350(0.64)^{*}$ & $2.694(1.13)^{*}$ & $11.660(1.10)^{*}$ & $0.19(0.08)^{*}$ \\
\hline Energy content (Mcal/kg) & $0.076(0.00)^{*}$ & $0.017(0.01)^{*}$ & $0.060(0.01)^{*}$ & $0.22(0.09)^{*}$ \\
\hline TS (\%Brix value) & $19.900(0.91)^{*}$ & $5.368(1.78)^{*}$ & $14.530(1.61)^{*}$ & $0.27(0.09)^{*}$ \\
\hline
\end{tabular}

${ }^{1}$ Phenotypic $\left(\sigma_{p}^{2}\right)$, additive genetic $\left(\sigma_{\alpha}^{2}\right)$, and residual $\left(\sigma_{r}^{2}\right)$ variance, and heritability $\left(h^{2}\right)$ estimates (SE in parentheses).

$* P<0.05$. 
stein cows. Genetic variance and heritability estimates, together with genetic and phenotypic correlations, are reported here for the first time.

Previous, mostly small-scale studies have focused on colostrum composition and mainly on immunoglobulin concentration. Large-scale studies on colostrum composition are scarce; only Morrill et al. (2012) and Dunn et al. (2017) included large numbers of Holstein or Friesian cows in their studies (494 and 1,050, respectively).

In the present study, mean colostrum yield was $6.2 \pm$ $3.8 \mathrm{~kg}$, which is very similar to that reported by Kehoe et al. (2011) and about 8.0\% lower than that reported by Conneely et al. (2013). Colostrum collection time in these studies was similar to ours. Quigley et al. (2013) reported a mean colostrum yield of $9.5 \pm 3.2 \mathrm{~L}$ but mean collection time after calving was $6.1 \pm 3.2 \mathrm{~h}$, whereas, in this study, mean collection time was $3.9 \pm 3.2 \mathrm{~h}$. Mean colostrum fat content $(6.37 \pm 3.33 \%)$ was similar to those reported in previous publications (Kehoe et al., 2007; Morrill et al., 2012; Dunn et al., 2017). Mean protein content at $17.83 \pm 3.97 \%$ was about $30 \%$ higher than estimates reported previously (Kehoe et al., 2007; Morrill et al., 2012; Dunn et al., 2017), whereas mean colostrum lactose content $(2.15 \pm 0.73 \%)$ was about $20 \%$ lower than that reported in previous publications (Kehoe et al., 2007; Morrill et al., 2012; Dunn et al., 2017). The latter discrepancies are difficult to explain because comparisons among studies are almost impossible because of differences in colostrum definition and yield, time interval between calving and first milking, cow genetics, regions, rearing systems, and diet.

Furthermore, mean colostrum TS content in the present study (measured with a Brix refractometer) was $25.8 \pm 4.7 \%$, very similar to that reported in other studies (23.8\%, Quigley et al., 2013; 24.3\%, Bartier et al., 2015; 26.3\%, Bielmann et al., 2010). Kehoe et al. (2007) and Morrill et al. (2012) reported mean TS content (measured by MilkoScan) of $27.6 \%$ and $22.2 \%$, respectively.

Overall, colostrum composition of cows included in the present study was within the range reported in the literature; therefore, results of the genetic study could be generally applicable to the Holstein population.
Heritability of colostrum yield in our study was not different from zero. The only relevant reference in the literature is that of Conneely et al. (2013), who reported a heritability estimate of $0.21 \pm 0.08$. Results of the 2 studies are not comparable because the latter was based on cows from several different breeds together with crossbreds. Moreover, differences in estimates may be due to method of estimation, sample size, population structure, and data dispersion patterns.

A moderate heritability (0.21) of colostrum fat content was estimated in the present study; there are no other references in the literature. In contrast, studies reporting heritabilities of whole milk fat content are numerous. Specifically, for Holsteins, some studies report similar moderate estimates (Vallas et al., 2010; Tiezzi et al., 2013; Petrini et al., 2016), whereas others (Miglior et al., 2006; Bastin et al., 2011; Costa et al., 2018) report higher estimates. Comparisons are difficult to make, considering that heritability estimates of milk fat content are usually derived from records of several thousand cows and hundreds of different farms. Whether colostrum and whole milk fat contents are associated is unknown; this would be a very interesting area for future research.

A moderately low heritability (0.19) of colostrum protein content was estimated in the present study; again, there are no references in the literature. For Holstein milk protein content, moderate heritabilities are reported by some authors (Vallas et al., 2010; Tiezzi et al., 2013; Petrini et al., 2016), whereas others (Miglior et al., 2006; Bastin et al., 2011; Costa et al., 2018) report high heritabilities. Differences could be attributed to compositional characteristics of colostrum and whole milk protein fractions; immunoglobulin and casein or albumin secretion may well be different traits. Again, whether colostrum and milk protein contents are associated is unknown.

Similarly, the estimated heritability for colostrum lactose content in the present study was moderately low (0.15). Reported heritability estimates for milk lactose content of Holstein cows are much higher (Tiezzi et al., 2013; Petrini et al., 2016; Costa et al., 2018). Heritability estimates for colostrum total solids (0.27)

Table 3. Genetic (above diagonal) and phenotypic (below diagonal) correlations between colostrum traits (SE in parentheses)

\begin{tabular}{|c|c|c|c|c|c|c|}
\hline Trait & Yield & $\begin{array}{c}\text { Fat } \\
\text { content }\end{array}$ & $\begin{array}{l}\text { Protein } \\
\text { content }\end{array}$ & $\begin{array}{l}\text { Lactose } \\
\text { content }\end{array}$ & $\begin{array}{l}\text { Energy } \\
\text { content }\end{array}$ & $\begin{array}{c}\mathrm{TS} \\
(\% \text { Brix })\end{array}$ \\
\hline Yield & & $0.41(0.41)$ & $0.61(0.53)$ & $-0.66(0.70)$ & $0.33(0.32)$ & $0.49(0.46)$ \\
\hline Fat content & $0.06(0.03)$ & & $-0.07(0.33)$ & $-0.12(0.36)$ & $0.89(0.11)^{*}$ & $0.18(0.32)$ \\
\hline Protein content & $-0.13(0.03)^{*}$ & $0.01(0.06)$ & & $-0.96(0.18)^{*}$ & $0.36(0.31)$ & $0.97(0.03)^{*}$ \\
\hline Lactose content & $0.16(0.03)^{*}$ & $-0.08(0.05)$ & $-0.56(0.04)^{*}$ & & $-0.45(0.34)$ & $-0.89(0.23)^{*}$ \\
\hline Energy content & $-0.02(0.03)$ & $0.75(0.02)^{*}$ & $0.60(0.04)^{*}$ & $-0.39(0.05)^{*}$ & & $0.61(0.23)^{*}$ \\
\hline TS (\% Brix) & $-0.10(0.03)^{*}$ & $0.15(0.05)^{*}$ & $0.94(0.01)^{*}$ & $-0.52(0.04)^{*}$ & $0.69(0.03)^{*}$ & \\
\hline
\end{tabular}

$* P<0.05$. 
and energy content $(0.22)$ are reported here for the first time. The latter is quite similar to that of colostrum fat content. No similar references could be found in the literature.

Significant genetic variance estimates derived for all colostrum component and energy measurements suggest that genetic selection might actually improve these traits. Successful genetic selection for traits with similar heritabilities such as milk yield $\left(\mathrm{h}^{2}=0.20-0.50\right.$; Castillo-Juarez et al., 2000; Windig et al., 2006; Bastin et al., $2011)$ and SCC $\left(\mathrm{h}^{2}=0.03-0.11\right.$; Heringstad et al., 2005; Koeck et al., 2012) is already performed and included in breeding programs worldwide. Both the magnitude of heritability estimates and the amount of genetic variance of colostrum quality traits indicate that genetic selection should be feasible and undoubtedly beneficial for the newborn calf. Of course, before the application of such selection programs, it is necessary to investigate genetic correlations among colostrum traits and other traits included in the breeding goal.

The heritability estimate of colostrum TS content in the present study was based on values obtained onfarm using a Brix refractometer, which is a credible method for indirect assessment of colostrum immunoglobulin concentration (Bielmann et al., 2010; Bartier et al., 2015). This combined with the strong and positive genetic correlation between TS and protein content led us to speculate on favorable perspectives regarding genetic selection for high immunoglobulin content in colostrum. Phenotypes can be collected easily and at a very low cost, and genetic selection for TS measured with a Brix refractometer will result in genetic progress on colostrum protein content, and therefore on its immunoglobulin content, as well. Moreover, the significant genetic correlation between TS and energy content indicates that the latter could be simultaneously improved.

In the present study, we detected no significant genetic correlations between either colostrum fat and protein content or colostrum fat and lactose content. This is opposite to the strong positive genetic correlations of milk fat with protein and lactose contents reported in the literature (Miglior et al., 2006; Petrini et al., 2016; Costa et al., 2018). Different mechanisms for colostrogenesis and lactogenesis probably explain these differences between colostrum and milk.

Moreover, the absence of genetic correlations between colostrum yield and quality traits in the present study is in contrast to negative correlations previously reported between milk yield and content (Loker et al., 2009; Petrini et al., 2016; Costa et al., 2018). Absence of genetic correlation in the present study is attributed to the absence of genetic variance in colostrum yield.
If confirmed, the lack of any association between colostrum yield and quality would allow selection of cows that produce high-quality colostrum with no effect on colostrum yield.

Furthermore, some statistically significant phenotypic correlations among colostrum yield and quality traits were detected in the present study and are reported here for the first time. The negative phenotypic correlation between milk fat and lactose content, which is reported in several studies (Miglior et al., 2006; Stoop et al., 2007; Loker et al., 2009), did not exist for colostrum content in the present study. Moreover, the negative phenotypic correlation among milk yield and its protein content (Miglior et al., 2006; Vallas et al., 2010; Costa et al., 2018) was evident in the present study for colostrum yield and protein content. Interestingly, we detected no phenotypic correlation between colostrum yield and fat content, despite the statistically significant phenotypic variance in both traits. The negative phenotypic correlation between milk yield and fat content is well established (Miglior et al., 2006; Petrini et al., 2016; Costa et al., 2018). The latter obviously results from the dilution effect, because lactose is the principal regulator of milk yield (Bastin et al., 2011). Mechanisms affecting colostrum yield must be clarified before a pertinent explanation is reached.

The negative phenotypic correlations of colostrum lactose content with protein, TS, and energy content and the positive correlation with colostrum yield are very similar to those reported for milk (Miglior et al., 2006; Loker et al., 2009). This is clearly due to the dilution effect mentioned in the literature (Dunn et al., 2017) and indicates the great importance of collecting colostrum as soon as possible after parturition to secure both transfer of passive immunity and adequate nutrition.

The strong and statistically significant positive genetic and phenotypic correlations between the Brixbased colostrum TS and protein contents measured in the laboratory confirm the usefulness of the Brix refractometer for indirect assessment of colostrum immunoglobulin content. Total solids content was also correlated with energy content, presenting a practical management advantage; the most suitable colostrum for passive transfer of immunity provides, at the same time, the best nutrition for the newborn calf.

\section{CONCLUSIONS}

Estimates of genetic variance and heritability of colostrum quality traits were statistically significant and, therefore, these traits may be considered amenable to improvement with selective breeding. The highest 
heritability was observed for indirect on-farm assessment of immunoglobulin content; that is, the measurement of TS with a Brix refractometer. Considering the significance of calf health and welfare for the profitability of dairy herds, the strong genetic correlation of Brix measurements and other colostrum quality traits further corroborates the adoption of the former as an easy and low-cost way to collect animal phenotypes. Because this is the first time that heritability estimates of colostrum quality traits have been reported for Holstein dairy cows, we acknowledge that more research is needed based on independent data to confirm results. Further studies should focus on repeatability estimates in subsequent parities, the identification of genomic regions for more accurate insights into the molecular architecture of colostrum traits, and the association of colostrum with other productive or functional traits.

\section{ACKNOWLEDGMENTS}

This study was sponsored by General Secretariat for Research and Technology (GSRT, Athens, Greece) and Hellenic Foundation for Research and Innovation (HFRI, Athens, Greece). Furthermore, the first author is grateful to the farmers who embraced this study.

\section{REFERENCES}

Arthur, G. H., D. E. Nokes, H. Pearson, and T. J. Parkinson. 1996. The development of the conceptus. Pages 51-109 in Pregnancy and Parturition in Veterinary Reproduction and Obstetrics. 7th ed. W. B. Saunders, Philadelphia, PA.

Bartier, A. L., M. C. Windeyer, and L. Doepel. 2015. Evaluation of on-farm tools for colostrum quality measurement. J. Dairy Sci. 98:1878-1884. https://doi.org/10.3168/jds.2014-8415.

Bastin, C., N. Gengler, and H. Soyeurt. 2011. Phenotypic and genetic variability of production traits and milk fatty acid contents across days in milk for Walloon Holstein first-parity cows. J. Dairy Sci. 94:4152-4163. https://doi.org/10.3168/jds.2010-4108.

Bielmann, V., J. N. R. Gillan, A. L. Perkins, L. Skidmore, S. Godden, and K. E. Leslie. 2010. An evaluation of Brix refractometry instruments for measurement of colostrum quality in dairy cattle. J. Dairy Sci. 93:3713-3721. https://doi.org/10.3168/jds.2009-2943.

Blum, J. W., and H. Hammon. 2000. Colostrum effects on the gastrointestinal tract, and on nutritional, endocrine and metabolic parameters in neonatal calves. Livest. Prod. Sci. 66:151-159. https: //doi.org/10.1016/S0301-6226(00)00222-0.

Castillo-Juarez, H., P. A. Oltenacu, R. W. Blake, C. E. Mcculloch, and E. G. Cienfuegos-Rivas. 2000. Effect of herd environment on the genetic and phenotypic relationships among milk yield, conception rate, and somatic cell score in Holstein cattle. J. Dairy Sci. 83:807-814. https://doi.org/10.3168/jds.S0022-0302(00)74943-5.

Conneely, M., D. P. Berry, R. Sayers, J. P. Murphy, I. Lorenz, M. L. Doherty, and E. Kennedy. 2013. Factors associated with the concentration of immunoglobulin $\mathrm{G}$ in the colostrum of dairy cows. Animal 7:1824-1832. https://doi.org/10.1017/S1751731113001444.

Costa, A., N. Lopez-Villalobos, G. Visentin, M. De Marchi, M. Cassandro, and M. Penasa. 2018. Heritability and repeatability of milk lactose and its relationships with traditional milk traits, somatic cell score and freezing point in Holstein cows. Animal 13:909-916. https://doi.org/10.1017/S1751731118002094.
Dunn, A., A. Ashfield, B. Earley, M. Welsh, A. Gordon, and S. J. Morrison. 2017. Evaluation of factors associated with immunoglobulin $\mathrm{G}$, fat, protein, and lactose concentrations in bovine colostrum and colostrum management practices in grassland-based dairy systems in Northern Ireland. J. Dairy Sci. 100:2068-2079. https://doi.org/ 10.3168 /jds.2016-11724.

Ferguson, J. D., D. T. Galligan, and N. Thomsen. 1994. Principal descriptors of body condition score in Holstein cows. J. Dairy Sci. 77:2695-2703. https://doi.org/10.3168/jds.S0022-0302(94)77212 $-\mathrm{X}$.

Fleenor, W. A., and G. H. Stott. 1981. Single radial immunodiffusion analysis for quantitation of colostral immunoglobulin concentration. J. Dairy Sci. 64:740-747. https://doi.org/10.3168/jds.S0022 $-0302(81) 82642-2$

Foley, J. A., and D. E. Otterby. 1978. Availability, storage, treatment, composition, and feeding value of surplus colostrum. J. Dairy Sci. 61:1033-1060. https://doi.org/10.3168/jds.S0022-0302(78)83686 $-8$.

Gelsinger, S. L., A. M. Smith, C. M. Jones, and A. J. Heinrichs. 2015. Technical note: Comparison of radial immunodiffusion and ELISA for quantification of bovine immunoglobulin $\mathrm{G}$ in colostrum and plasma. J. Dairy Sci. 98:4084-4089. https://doi.org/10.3168/jds .2014-8491.

Gilmour, A. R., B. J. Gogel, B. R. Cullis, and R. Thompson. 2009. ASReml User Guide Release 3.0 VSN International Ltd., Hemel Hempstead, UK.

Godden, S. 2008. Colostrum management for dairy calves. Vet. Clin. North Am. Food Anim. Pract. 24:19-39. https://doi.org/10.1016/ j.cvfa.2007.10.005.

Heringstad, B., Y. M. Chang, D. Gianola, and G. Klemetsdal. 2005. Genetic analysis of clinical mastitis, milk fever, ketosis, and retained placenta in three lactations of Norwegian red cows. J. Dairy Sci. 88:3273-3281. https://doi.org/10.3168/jds.S0022 -0302(05)73010-1.

Jaster, E. H. 2005. Evaluation of quality, quantity, and timing of colostrum feeding on immunoglobulin G1 absorption in Jersey calves. J. Dairy Sci. 88:296-302. https://doi.org/10.3168/jds.S0022 -0302(05)72687-4.

Kehoe, S. I., A. J. Heinrichs, M. L. Moody, C. M. Jones, and M. R. Long. 2011. Comparison of immunoglobulin G concentrations in primiparous and multiparous bovine colostrum. Prof. Anim. Sci. 27:176-180. https://doi.org/10.15232/S1080-7446(15)30471-X.

Kehoe, S. I., B. M. Jayarao, and A. J. Heinrichs. 2007. A survey of bovine colostrum composition and colostrum management practices on Pennsylvania dairy farms. J. Dairy Sci. 90:4108-4116. https:// doi.org/10.3168/jds.2007-0040.

Koeck, A., F. Miglior, D. F. Kelton, and F. S. Schenkel. 2012. Alternative somatic cell count traits to improve mastitis resistance in Canadian Holsteins. J. Dairy Sci. 95:432-439. https://doi.org/10 $.3168 /$ jds.2011-4731.

Larson, B. L. 1992. Immunoglobulins of the mammary secretions. Pages 140-145 in Advanced Dairy Chemistry, Vol. 1: Proteins. P. F. Fox and P. L. H. McSweeney, ed. Elsevier, London, UK. https:// doi.org/10.1007/978-1-4419-8602-3.

Loker, S. F., C. Bastin, F. Miglior, A. Sewalem, J. Fatehi, L. R. Schaeffer, and J. Jamrozik. 2009. Genetic parameters of body condition score and milk production traits in Canadian Holsteins. In Dairy Cattle Breeding and Genetics Committee Meeting. Centre for Genetic Improvement of Livestock, University of Guelph, Guelph, ON, Canada.

McGuirk, S. M., and M. Collins. 2004. Managing the production, storage, and delivery of colostrum. Vet. Clin. North Am. Food Anim. Pract. 20:593-603. https://doi.org/10.1016/j.cvfa.2004.06.005.

Miglior, F., A. Sewalem, J. Jamrozik, D. M. Lefebvre, and R. K. Moore. 2006. Analysis of milk urea nitrogen and lactose and their effect on longevity in Canadian dairy cattle. J. Dairy Sci. 89:48864894. https://doi.org/10.3168/jds.S0022-0302(06)72537-1.

Morrill, K. M., E. M. Conrad, A. Lago, J. Campbell, J. Quigley, and H. Tyler. 2012. Nationwide evaluation of quality and composition 
of colostrum on dairy farms in the United States. J. Dairy Sci. 95:3997-4005. https://doi.org/10.3168/jds.2011-5174.

NRC. 2001. Nutrient Requirements of Dairy Cattle. 7th rev. ed. Natl. Acad. Sci., Washington, DC.

Petrini, J., L. H. S. Iung, M. A. P. Rodriguez, M. Salvian, F. Pertille, G. A. Rovadoscki, L. D. Cassoli, L. L. Coutinho, P. F. Machado, G. R. Wiggans, and G. B. Mourao. 2016. Genetic parameters for milk fatty acids, milk yield and quality traits of a Holstein cattle population reared under tropical conditions. J. Anim. Breed. Genet. 133:384-395. https://doi.org/10.1111/jbg.12205.

Quigley, J. D., A. Lago, C. Chapman, P. Erickson, and J. Polo. 2013 Evaluation of the Brix refractometer to estimate immunoglobulin G concentration in bovine colostrum. J. Dairy Sci. 96:1148-1155. https://doi.org/10.3168/jds.2012-5823.

Stoop, W. M., H. Bovenhuis, and J. A. M. van Arendonk. 2007. Genetic parameters for milk urea nitrogen in relation to milk production traits. J. Dairy Sci. 90:1981-1986. https://doi.org/10.3168/ jds.2006-434.

Tiezzi, F., D. Pretto, M. De Marchi, M. Penasa, and M. Cassandro. 2013. Heritability and repeatability of milk coagulation properties predicted by mid-infrared spectroscopy during routine data recording, and their relationships with milk yield and quality traits. Animal 7:1592-1599. https://doi.org/10.1017/S1751731113001195.

Tsioulpas, A., A. S. Grandison, and M. J. Lewis. 2007. Changes in physical properties of bovine milk from the colostrum period to early lactation. J. Dairy Sci. 90:5012-5017. https://doi.org/10 $.3168 /$ jds.2007-0192.

Vallas, M., H. Bovenhuis, T. Kaart, K. Pärna, H. Kiiman, and E. Pärna. 2010. Genetic parameters for milk coagulation properties in Estonian Holstein cows. J. Dairy Sci. 93:3789-3796. https://doi .org/10.3168/jds.2009-2435.

Weaver, D. M., J. W. Tyler, D. C. Van Metre, D. E. Hostetler, and G. M. Barrington. 2000. Passive transfer of colostral immunoglobulins in calves. J. Vet. Intern. Med. 14:569-577. https://doi.org/10 $.1111 /$ j.1939-1676.2000.tb02278.x.

Windig, J. J., M. P. L. Calus, B. Beerda, and R. F. Veerkamp. 2006 Genetic correlations between milk production and health and fertility depending on herd environment. J. Dairy Sci. 89:1765-1775. https://doi.org/10.3168/jds.S0022-0302(06)72245-7. 